\title{
Isolation of Geobacillus stearothermophilus \\ L-arabinose Isomerase for the Production of the Novel Food Ingredient D-tagatose
}

\begin{abstract}
Monika Van Holsbeeck
KU Leuven, KAHO Sint-Lieven, Faculty of Engineering Technology, Department of Microbial and Molecular Systems (M2S), Cluster for Bioengineering Technology (CBeT), Laboratory of Enzyme, Fermentation and Brewing Technology (EFBT)

Gebroeders De Smetstraat 1, B-9000 Gent, Belgium. Tel: 32-(0)9265-8613

KU Leuven, Faculty of Engineering Science, Department of Chemical Engineering (CIT),

Chemical and Biochemical Process Technology and Control (BioTeC)

Willem de Croylaan 46, B-3001 Heverlee, Belgium. Tel: 32-(0)1632-2675
\end{abstract}

\section{Efstathia Tsakali}

KU Leuven, Faculty of Engineering Science, Department of Chemical Engineering (CIT), Chemical and Biochemical Process Technology and Control (BioTeC)

Willem de Croylaan 46, B-3001 Heverlee, Belgium. Tel: 32-(0)1632-2675

\section{Evelien Syryn}

KU Leuven, KAHO Sint-Lieven, Faculty of Engineering Technology, Department of Microbial and Molecular Systems (M2S), Cluster for Bioengineering Technology (CBeT), Laboratory of Enzyme, Fermentation and Brewing Technology (EFBT)

Gebroeders De Smetstraat 1, B-9000 Gent, Belgium. Tel: 32-(0)9265-8613

\section{Carolien Van den Bussche}

KU Leuven, KAHO Sint-Lieven, Faculty of Engineering Technology, Department of Microbial and Molecular Systems (M2S), Cluster for Bioengineering Technology (CBeT), Laboratory of Enzyme, Fermentation and Brewing Technology (EFBT)

Gebroeders De Smetstraat 1, B-9000 Gent, Belgium. Tel: 32-(0)9265-8613 


\title{
Guido Aerts
}

KU Leuven, KAHO Sint-Lieven, Faculty of Engineering Technology, Department of Microbial and Molecular Systems (M2S), Cluster for Bioengineering Technology (CBeT),

Laboratory of Enzyme, Fermentation and Brewing Technology (EFBT)

Gebroeders De Smetstraat 1, B-9000 Gent, Belgium. Tel: 32-(0)9265-8613

Jan Van Impe

KU Leuven, Faculty of Engineering Science, Department of Chemical Engineering (CIT),

Chemical and Biochemical Process Technology and Control (BioTeC)

Willem de Croylaan 46, B-3001 Heverlee, Belgium. Tel: 32-(0)1632-2675

Ilse Van de Voorde (Corresponding author)

KU Leuven, KAHO Sint-Lieven, Faculty of Engineering Technology, Department of Microbial and Molecular Systems (M2S), Cluster for Bioengineering Technology (CBeT), Laboratory of Enzyme, Fermentation and Brewing Technology (EFBT)

Gebroeders De Smetstraat 1, B-9000 Gent, Belgium. Tel: 32-(0)9265-8613

Received: September 18, 2014 Accepted: December 5, 2014 Published: January 8, 2015

Doi: 10.5296/jab.v3n1.6879 URL: http://dx.doi.org/10.5296/jab.v3n1.6879

\begin{abstract}
D-tagatose, a low-calorie bulk sweetener, can be produced from D-galactose with an L-arabinose isomerase (L-AI) from Geobacillus stearothermophilus. Isolation of L-AI enzyme, intracellularly expressed in Escherichia coli, was studied by means of sonication, by chemical cell disruption and by a combined disruption approach. Conditions for cell disruption through sonication, e.g., sonication time, duty cycle, power and sample volume were determined for the wild type (WT) enzyme which was produced without an inducible expression system. The highest release was observed at a power of $120 \mathrm{~W}$ after 5 minutes of sonication with a duty cycle of $50 \%$ and sample volume of $60.0 \mathrm{~mL}$ resulting in a relative L-AI activity of $92.5 \pm 0.9 \%$. Chemical cell disruption with $16.5 \mathrm{mM}$ triton X-100 for 17 hours gave even better results compared to sonication, namely, a relative $\mathbb{L}-\mathrm{AI}$ activity in the crude extract of $95.6 \pm 1.2 \%$. Additional experiments were performed on cell disruption of the wild type enzyme produced with an inducible expression system $\left(\mathrm{WT}_{\mathrm{i}}\right)$. Treatment of $\mathrm{WT}_{\mathrm{i}}$ enzyme with $16.5 \mathrm{mM}$ triton X-100 for 17 hours led to a lower relative L-AI activity, namely, $84.0 \pm 0.5 \%$. A combined approach of a prior chemical lysis with triton X-100 followed by
\end{abstract}


sonication led to a further increase of L-AI activity towards $89.6 \pm 0.3 \%$.

Keywords: D-tagatose, L-arabinose isomerase, Geobacillus stearothermophilus, Cell disruption, Sonication, Triton X-100 


\section{Introduction}

During recent years, D-tagatose has attracted a lot of attention due to its wide range of healthy benefits. D-tagatose is a naturally occurring bulk sweetener exhibiting a low caloric value of $1.5 \mathrm{kcal} \mathrm{g}^{-1}$ and approximately $92 \%$ of the sweetness of sucrose (Kim, 2004; Liang et al., 2012; Lu et al., 2008; Oh, 2007; Skytte, 2006; Vastenavond et al., 2012). Furthermore, D-tagatose has a low glycaemic response, prebiotic properties and does not cause tooth decay. These benefits make D-tagatose highly suitable for utilization in healthy food and nutrition for diabetics (Liang et al., 2012; Lu et al., 2008; Oh, 2007; Skytte, 2006; Vastenavond et al., 2012).

D-tagatose can be produced either chemically or biochemically from D-galactose (Cheetham \& Wootton, 1993; Jorgensen et al., 2004; Kim et al., 2001; Kim et al., 2003; Kim, 2004; Oh, 2007; Skytte, 2006; Vastenavond et al., 2012). Chemical conversion of D-galactose is effectuated under alkaline conditions, in the presence of calcium hydroxide and a catalyst (Cheetham \& Wootton, 1993; Jorgensen et al., 2004; Kim, 2004; Vastenavond et al., 2012). Chemical production of D-tagatose is however not economically feasible due to by-product formation and complex purification steps (Jorgensen et al., 2004; Kim et al., 2003). Due to the negative aspects of chemical D-tagatose production, a biochemical process is preferred. D-galactose can be isomerised to D-tagatose with an L-arabinose isomerase (L-AI) enzyme (EC 5.3.1.4) from Geobacillus stearothermophilus (Jorgensen et al., 2004; Kim et al., 2001; Kim, 2004; Vastenavond et al., 2012). The L-AI is expressed in the host organism E. coli, which implies an intracellular L-AI expression (Jorgensen et al., 2004; Kim \& Oh, 2005; Lee et al., 2004; Lee et al., 2005; Liang et al., 2012; Rhimi \& Bejar, 2006).

For application of free or immobilised L-AI within the production process of D-tagatose, the enzyme needs first to be isolated in case of an intracellular expression system. Methods for cell disruption can be divided into mechanical and non-mechanical methods. Mechanical disruption methods such as sonication are non-specific, this in contrast to non-mechanical procedures (Falconer et al., 1997; Geciova et al., 2002; Harrison, 1991; Middelberg, 1995; Seddon et al., 2004). Cell disruption through sonication can be attributed to shear forces, shock waves and heating. Ultrasound can potentially also cause inactivation of enzymes. The major cause of this enzyme inactivation is a free-radical production (Alzamora et al., 2011; Ananta et al., 2005; Bermúdez-Aguirre et al., 2011; Mawson et al. 2011; Santos et al., 2009). The efficiency of sonication depends on several parameters e.g. sonication time, duty cycle, power and volume (Agrawal \& Pandit, 2003; Benov \& Al-Ibraheem, 2002; Feliu et al., 1998; Geciova et al., 2002; Joyce et al., 2003; Kapucu et al., 2000; Kuboi et al., 1995; Özbek \& Ülgen, 2000). For each parameter, a compromise needs to be made between maximal cell disruption and minimal enzyme inactivation. Non-mechanical methods can be divided into physical, enzymatic and chemical techniques. A broad variety of chemical components can be used for chemical cell disruption, e.g., antibiotics, chelating agents, detergents, chaotropes, solvents, hydroxides or hypochlorites (Falconer et al., 1997; Geciova et al., 2002; Harrison, 1991; Middelberg, 1995; Seddon et al., 2004).

In this study, several methods for cell disruption of E. coli for isolation of the L-AI from 
Geobacillus stearothermophilus were investigated, more specific mechanical disruption by sonication and chemical cell disruption with triton X-100, tween80, urea and isopropanol, respectively. Moreover, the effect of combining chemical lysis and sonication on L-AI activity was investigated. The order of applying different techniques could also play an important role. Chemical treatment can damage the cell wall so that sonication is facilitated. On the other hand, chemical reagents can, next to cell disruption, partially solubilise inclusion bodies which are accessible after cell disruption through sonication (Feliu et al., 1998; Ho et al., 2006).

\section{Material and Methods}

\subsection{Cultivation of E. coli and Expression of L-AI Enzyme}

The L-AI enzyme from Geobacillus stearothermophilus was expressed intracellularly in E. coli BL21. The wild type (WT) strain was supplied by the Center for Protein Engineering (CIP, University of Liège, Belgium) and lacks the need for induction through the removal of the LacI repressor. Cells were cultivated in a bioreactor (New Brunswick Scientific co., inc. U.S.A. BioFlo IV) containing 7.0 L cultivation medium consisting of $16.8 \mathrm{~mL} \mathrm{~L}^{-1}$ glycerol [95\% (v/v)] (Merck), $10.0 \mathrm{~g} \mathrm{~L}^{-1}$ yeast extract (Organo Technie), $15.0 \mathrm{~g} \mathrm{~L}^{-1} \mathrm{~K}_{2} \mathrm{HPO}_{4}$ (Caldic), $7.50 \mathrm{~g} \mathrm{~L}^{-1} \mathrm{KH}_{2} \mathrm{PO}_{4}$ (Caldic), $3.00 \mathrm{~g} \mathrm{~L}^{-1}\left(\mathrm{NH}_{4}\right)_{2} \mathrm{SO}_{4}$ (Caldic), $2.20 \mathrm{~g} \mathrm{~L}^{-1} \mathrm{Na}$-citrate (Caldic), $1.50 \mathrm{~g} \mathrm{~L}^{-1} \mathrm{MgSO}_{4} \cdot 7 \mathrm{H}_{2} \mathrm{O}$ (Caldic), $0.197 \mathrm{~g} \mathrm{~L}^{-1} \mathrm{MnCl}_{2} \cdot 4 \mathrm{H}_{2} \mathrm{O}$ (Chem-Lab), $0.0125 \mathrm{~g} \mathrm{~L}^{-1}$ chloramphenicol (Sigma-Aldrich) and $2.00 \mathrm{~mL} \mathrm{~L}^{-1}$ trace solution. The trace solution consisted of $33.8 \mathrm{~g} \mathrm{~L}^{-1} \mathrm{Zn}\left(\mathrm{CH}_{3} \mathrm{COO}\right)_{2} \cdot 2 \mathrm{H}_{2} \mathrm{O}$ (VWR), $14.1 \mathrm{~g} \mathrm{~L}^{-1} \mathrm{Na}-\mathrm{EDTA} \cdot 2 \mathrm{H}_{2} \mathrm{O}$ (VWR), $3.00 \mathrm{~g} \mathrm{~L} \mathrm{~L}^{-1} \mathrm{H}_{3} \mathrm{BO}_{3}$ (Alfa Aesar), $2.50 \mathrm{~g} \mathrm{~L}^{-1} \mathrm{CoCl}_{2} \cdot 6 \mathrm{H}_{2} \mathrm{O}$ (Alfa Aesar), $2.10 \mathrm{~g} \mathrm{~L}^{-1}$ $\mathrm{Na}_{2} \mathrm{MoO}_{4} \cdot 2 \mathrm{H}_{2} \mathrm{O}$ (VWR), $1.50 \mathrm{~g} \mathrm{~L}^{-1} \mathrm{CuCl}_{2} \cdot 2 \mathrm{H}_{2} \mathrm{O}$ (VWR) and $0.197 \mathrm{~g} \mathrm{~L}^{-1} \mathrm{MnCl}_{2} \cdot 4 \mathrm{H}_{2} \mathrm{O}$ (Chem-Lab). The temperature was set at $25^{\circ} \mathrm{C}$ and the $\mathrm{pH}$ was controlled at 7.0 with $24.5 \%$ $\mathrm{NH}_{3}$ (v/v) (Brenntag). When glycerol was depleted, a concentrated feed was added to the bioreactor at a flow rate of $1.2 \mathrm{~mL} \mathrm{~min}^{-1}$. The feed consisted of $365 \mathrm{~mL} \mathrm{~L}^{-1}$ glycerol [95\% (v/v)] (Merck), $178 \mathrm{~g} \mathrm{~L}^{-1}$ yeast extract (Organo Technie), $1.00 \mathrm{~g} \mathrm{~L}^{-1} \mathrm{MgSO}_{4} \cdot 7 \mathrm{H}_{2} \mathrm{O}$ (Caldic), $0.394 \mathrm{~g} \mathrm{~L}^{-1} \mathrm{MnCl}_{2} \cdot 4 \mathrm{H}_{2} \mathrm{O}$ (Chem-Lab), $0.0250 \mathrm{~g} \mathrm{~L}^{-1}$ chloramphenicol (Sigma-Aldrich) and $1.00 \mathrm{~mL} \mathrm{~L}^{-1}$ trace solution. After 72 hours of fermentation, an optical density (OD) of 111 and dry matter content of $3.67 \%(\mathrm{w} / \mathrm{v})$ was reached. The effect of sonication time, duty cycle, power and sample volume on the efficiency of sonication as well as the screening of chemical components was investigated with the WT strain.

The effect of treatment time and concentration of triton X-100 as well as the combined disruption approaches on isolation of L-AI was investigated with E. coli BL21 with the wild type enzyme, which was produced with an inducible expression system $\left(\mathrm{WT}_{\mathrm{i}}\right)$. This strain, also supplied by the CIP, is different from the previous strain because it needs to be induced with isopropyl $\beta$-D-1-thiogalactopyranoside (IPTG). Furthermore, the carbon source during the cultivation was $20 \mathrm{~g} \mathrm{~L}^{-1}$ glucose (Tereos Syral) instead of glycerol. The feed contained $354 \mathrm{~g} \mathrm{~L}^{-1}$ glucose (Tereos Syral). The temperature before induction was set at $30^{\circ} \mathrm{C}$. After induction, the temperature was lowered to $25^{\circ} \mathrm{C}$. After 50 hours of fermentation, an OD of 107 and dry matter content of $3.87 \%(\mathrm{w} / \mathrm{v})$ was reached.

Cells were harvested by centrifugation (Awel centrifugation) at $4{ }^{\circ} \mathrm{C}$ for 30 minutes at 4000 
rpm and were washed with tris- $\mathrm{HCl}$ buffer [pH of 7.0, adjusted with $37 \%$ (w/w) $\mathrm{HCl}$ (VWR)] consisting of $50.0 \mathrm{mM}$ tris(hydroxymethyl)aminomethane) (tris, Sigma-Aldrich) and 1.00 $\mathrm{mM} \mathrm{MnCl}{ }_{2} \cdot 4 \mathrm{H}_{2} \mathrm{O}$ (Chem-Lab). Next, cells were centrifuged (Awel centrifugation) at $4{ }^{\circ} \mathrm{C}$ for 30 minutes at $4000 \mathrm{rpm}$. Finally, the washed pellet was diluted to the initial cell volume with tris- $\mathrm{HCl}$ buffer of $\mathrm{pH}$ 7.0. Afterwards, the D-tagatose production was determined. $0.500 \mathrm{~mL}$ intracellular enzyme was added to $1.500 \mathrm{~mL}$ D-galactose solution $\left[350 \mathrm{~g} \mathrm{~L}^{-1} \mathrm{D}\right.$-galactose (Inalco), $50.0 \mathrm{mM}$ tris, $1.00 \mathrm{mM} \mathrm{MnCl}_{2} .4 \mathrm{H}_{2} \mathrm{O}$ ] of $\mathrm{pH} 7.0$ [adjusted with $37 \%$ (w/w) $\mathrm{HCl}$ ]. Mixtures were incubated for 2 hours at $60^{\circ} \mathrm{C}$ in a water bath with shaking mechanism (Heto Birkerod Denmark). Subsequently, the D-tagatose concentration was determined with High-Performance Liquid Chromatography (HPLC) with Refractive Index (RI) detection. Determination of the D-tagatose concentration with HPLC was performed on a Bio-Rad Aminex Carbohydrate HPX-87P column $(300 \times 7.8 \mathrm{~mm})$. Samples were pretreated with 20 $\mu \mathrm{L} \mathrm{mL}{ }^{-1}$ Carrez I and II (VWR) in order to remove the proteins. Similar L-AI activities were found for the WT enzyme and $\mathrm{WT}_{\mathrm{i}}$ enzyme, namely $30.2 \pm 2.0$ and $29.0 \pm 0.3 \mathrm{~g} \mathrm{~L}^{-1}$ D-tagatose, respectively.

\subsection{Cell Disruption by Sonication}

Cell disruption was performed at $20 \mathrm{kHz}$ with a Branson Sonifier 250 equipped with a horn tip. The washed pellet of the WT enzyme was used for these experiments. Different parameters were tested including sonication time, duty cycle, power and sample volume. Sonication time was varied from 3 minutes to 10 minutes and the duty cycle was changed from 10 to $100 \%$. A duty cycle of $50 \%$ implies 0.5 seconds of pulsation and 0.5 seconds of rest. Power and sample volume were varied from 60 to $120 \mathrm{~W}$ and 30.0 to $120 \mathrm{~mL}$, respectively. All sonication experiments were performed on ice and were repeated four times. After cell disruption, cell suspensions were centrifuged (Awel centrifugation) at $4^{\circ} \mathrm{C}$ for 30 minutes at $4000 \mathrm{rpm}$ and the crude extract was separated from the cell debris. In the crude extract, the protein concentration and the relative L-AI activity was determined. The cell debris was washed with tris-HCl buffer followed by centrifugation for 30 minutes at 4000 rpm. Finally, the cell debris was diluted to the initial cell volume with tris- $\mathrm{HCl}$ buffer of $\mathrm{pH}$ 7.0 and the corresponding OD was measured. The mean value was calculated for the protein concentration, relative L-AI activity and OD and corresponding standard deviations were calculated.

\subsection{Chemical Cell Disruption}

For chemical cell disruption, initially different reagents were screened, namely $16.5 \mathrm{mM}$ triton X-100 (Sigma-Aldrich), $8.17 \mathrm{mM}$ tween80 (Merck), 2.00 M urea (Merck) and 1.31 M isopropanol (Merck). $50.0 \mathrm{~mL}$ washed pellet of the WT enzyme was incubated with these chemical reagents for 17 hours at $25^{\circ} \mathrm{C}$ and mixtures were stirred at $200 \mathrm{rpm}$ (IKA-Werke). All experiments were performed four times. After cell disruption, cell suspensions were post-treated in accordance to the sonication experiments. In addition, the effect of triton $\mathrm{X}-100$ concentration was investigated by incubating $50.0 \mathrm{~mL}$ washed pellet of $\mathrm{WT}_{\mathrm{i}}$ enzyme with $16.5,33.1$ and $49.6 \mathrm{mM}$ triton $\mathrm{X}-100$ at $25^{\circ} \mathrm{C}$ for 17 hours and mixtures were stirred at $200 \mathrm{rpm}$. The treatment time in the presence of $16.5 \mathrm{mM}$ triton X-100 was varied between 6 , 


\section{Macrothink}

17 and 28 hours at $25^{\circ} \mathrm{C}$ and mixtures were stirred at $200 \mathrm{rpm}$. All experiments were performed three times. After cell disruption, cell suspensions were post-treated in accordance to the sonication experiments.

\subsection{Combined Disruption Approach}

The effect of sonication followed by chemical treatment was evaluated by incubating washed pellet of $\mathrm{WT}_{\mathrm{i}}$ enzyme after sonication with $16.5 \mathrm{mM}$ triton $\mathrm{X}-100$ for 6 hours at $25^{\circ} \mathrm{C}$ and mixtures were stirred at $200 \mathrm{rpm}$. Sonication was performed at $120 \mathrm{~W}$ during 5 minutes with a duty cycle of $50 \%$ and sample volume of $60.0 \mathrm{~mL}$. The effect of a prior chemical lysis and subsequent sonication treatment was also investigated under similar operational conditions. After cell disruption, cell suspensions were post-treated in accordance to the sonication experiments. Results of the combined approaches were compared to the results of the individual disruption techniques.

\subsection{Protein Quantification}

The protein concentration was determined using the Bicinchoninic Acid Protein Assay Kit (BCA1, Sigma-Aldrich). $2.00 \mathrm{~mL}$ bicinchoninic acid (BCA) working reagent was added to $0.100 \mathrm{~mL}$ bovine serum albumin (BSA) standard $\left(0,200,400,600,800\right.$ and $1000 \mu \mathrm{L} \mathrm{mL}^{-1}$ BSA), blank or unknown sample in an appropriate dilution. Mixtures were incubated for 2 hours at $25^{\circ} \mathrm{C}$. After 2 hours, the absorbance was measured at $562 \mathrm{~nm}$ and protein concentrations were calculated according to the standard curve.

\subsection{Determination of Relative L-AI Activity}

To determine the L-AI activity, $0.500 \mathrm{~mL}$ crude extract was added to $1.500 \mathrm{~mL}$ D-galactose solution [350 $\mathrm{g} \mathrm{L}^{-1}$ D-galactose, $50.0 \mathrm{mM}$ tris, $1.00 \mathrm{mM} \mathrm{MnCl}_{2} .4 \mathrm{H}_{2} \mathrm{O}$ ] of $\mathrm{pH} 7.0$ [adjusted with $37 \%(\mathrm{w} / \mathrm{w}) \mathrm{HCl}$ ]. Mixtures were incubated for 2 hours at $60^{\circ} \mathrm{C}$ in a water bath with shaking mechanism (Heto Birkerod Denmark). Subsequently, the D-tagatose concentration was determined with the cysteine-carbazole method (Dische \& Borenfreund, 1951) or with High-Performance Liquid Chromatography (HPLC) with Refractive Index (RI) detection. With the cysteine-carbazole method, the reaction of the ketose, D-tagatose, with cysteine and carbazole in an acidic environment results in the formation of a purple product. The absorbance was measured at a wavelength of $560 \mathrm{~nm}$ with a Cary 100 Bio UV-Visible spectrophotometer from Varian. The relative L-AI activity was determined as follows:

$$
\text { Relative } L-A I \text { activity }(\%)=\frac{\text { activity of crude extract }\left(\frac{U}{m l}\right)}{\text { activity of cells }\left(\frac{U}{m l}\right)} \times 100
$$

\subsection{Determination of Optical Density}

The OD was determined by measuring the absorbance at a wavelength of $600 \mathrm{~nm}$ with a Cary 100 Bio UV-Visible spectrophotometer from Varian, after appropriate dilution. 


\section{MIN Macrothink}

\section{Results and Discussion}

\subsection{Effect of Sonication Time}

In this study, several parameters that influence the efficiency of cell disruption were investigated for isolation of Geobacillus stearothermophilus L-AI from E. coli in the context of the production of D-tagatose from D-galactose. The parameters were examined by sonication of washed pellet of WT type enzyme. The efficiency of sonication was evaluated based on the activity and protein concentration of the crude extract as well as the OD of the cell debris.

At first, the influence of sonication time on isolation of L-AI from Geobacillus stearothermophilus expressed in E. coli was studied at $120 \mathrm{~W}$ with a duty cycle of $50 \%$ and $60.0 \mathrm{~mL}$ sample volume. The sonication time was varied from 3 to 10 minutes. In order to evaluate the effect of the sonication time, the mean value of the protein concentration and relative L-AI activity in the crude extract and OD of the cell debris as well as the standard deviations were determined. Results are shown in Figure 1.

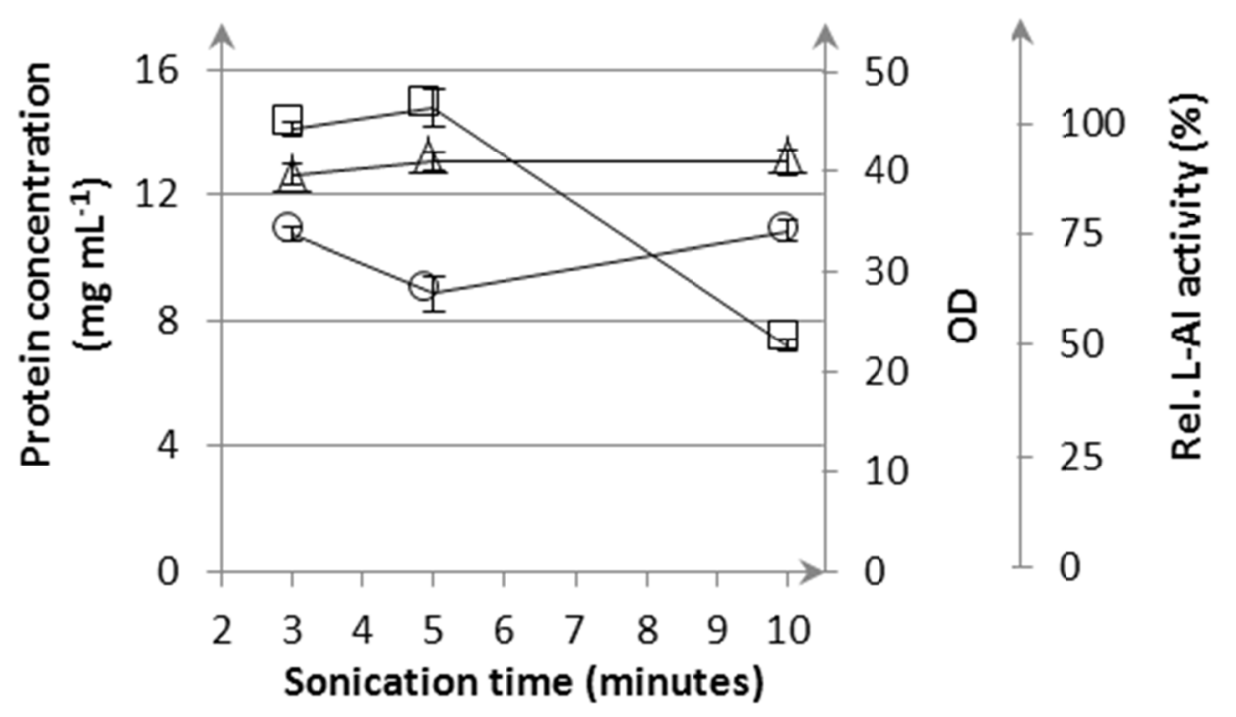

Figure 1. Effect of sonication time on the protein concentration ( $\square$ ) and relative L-AI activity $(\Delta)$ of the crude extract and OD of the cell debris $(\circ)$

A slightly higher protein concentration and lower OD of the cell debris was found when increasing sonication time from 3 to 5 minutes. The relative L-AI activity in the crude extract after 3 and 5 minutes of sonication was $89.5 \pm 1.1 \%$ and $92.5 \pm 0.9 \%$, respectively. Thus, an increase of the sonication time from 3 to 5 minutes led to an augmentation of the relative L-AI activity in the crude extract. These results confirm the higher protein concentration found in the crude extract after 5 minutes. A further increase of the sonication time up to 10 minutes did however not lead to a significant increase of the relative L-AI activity when 


\section{Il Macrothink}

compared to 5 minutes sonication. As it can be seen from the results in Figure 1, a strong decrease in protein concentration was noticed when increasing the sonication time from 5 to 10 minutes. The decline in protein concentration in the crude extract can be explained by inactivation of the released enzyme which resulted in an augmentation of the OD of the cell debris.

For all sonication times, a relative L-AI activity of approximately $50 \%$ was still noticed in the cell debris after cell disruption (data not shown). This is either due to an incomplete cell disruption or to the presence of inclusion bodies (Baneyx \& Mujacic, 2004; Sabate et al., 2010). The use of $E$. coli as host organism has several advantages, e.g., growth on inexpensive carbon sources and rapid biomass accumulation. However, it is not uncommon that recombinant proteins in E. coli fail to from a correct conformation and associate with each other to form insoluble aggregates known as inclusion bodies (Baneyx \& Mujacic, 2004; Sabate et al., 2010).

\subsection{Effect of Duty Cycle}

In the next phase, the effect of the duty cycle on the disruption performance was evaluated. Sonication was performed at $120 \mathrm{~W}$ for 5 minutes with $60.0 \mathrm{~mL}$ sample at various duty cycles, e.g., 10, 25, 50, 75 and 100\%. The effect of the duty cycle was examined by measuring the mean value of the protein concentration and relative L-AI activity in the crude extract and the OD of the cell debris as well as the standard deviations. The results are illustrated in Figure 2.

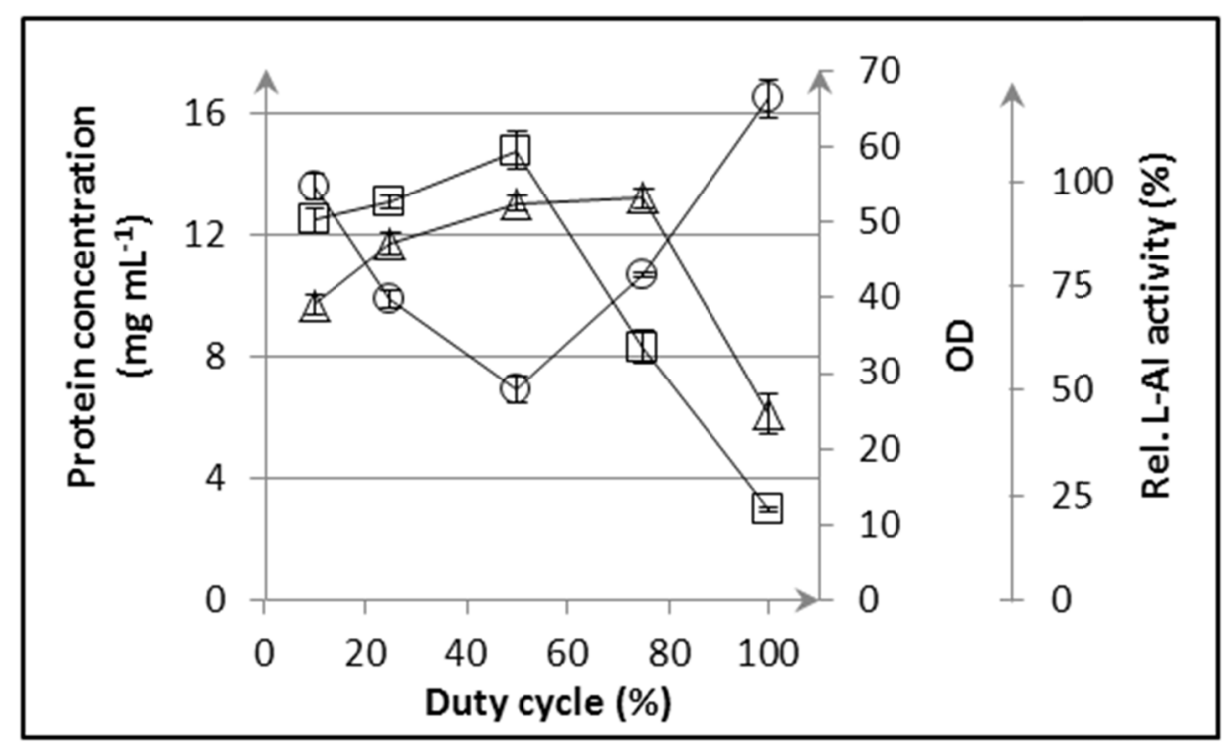

Figure 2. Effect of duty cycle on the protein concentration ( $\square$ ) and relative L-AI activity $(\Delta)$ of the crude extract and OD of the cell debris (O)

The increase of the duty cycle from 10 till $50 \%$ had a positive effect on the protein 


\section{Macrothink}

concentration and relative L-AI activity in the crude extract. An increase of the relative L-AI activity in the crude extract was observed, from $68.8 \pm 1.4 \%$ to $92.5 \pm 0.9 \%$. These results are in accordance to the decrease of OD of the cell debris. A further increase of the duty cycle to 75 and $100 \%$ negatively influenced the protein concentration in the crude extract. At the same time, an increase of the OD of the cell debris was observed which can be correlated to the inactivation of released proteins after cell disruption. Accordingly, highest isolation of active L-AI enzyme was achieved with a duty cycle of $50 \%$.

\subsection{Effect of Power}

The effect of the power on isolation of L-AI enzyme expressed in E. coli was investigated in this study within a range of 60 till $120 \mathrm{~W}$. Duty cycle, sonication time and sample volume were set at $50 \%, 5$ minutes and $60.0 \mathrm{~mL}$, respectively. Figure 3 shows the results of the effect of the power on isolation of the L-AI enzyme.

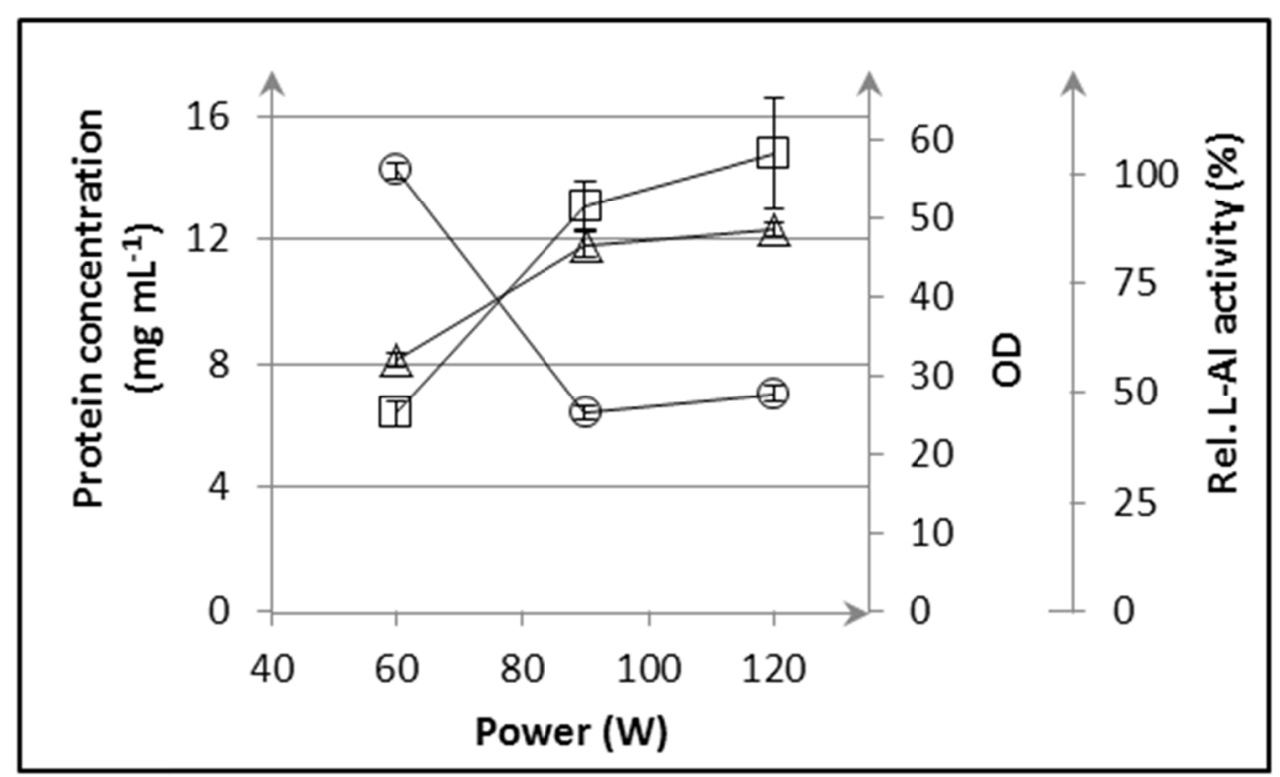

Figure 3. Effect of the power on the protein concentration ( $\square$ ) and relative L-AI activity $(\Delta)$ of the crude extract and OD of the cell debris (O)

By altering the power from 60 to $90 \mathrm{~W}$, a strong increase in protein concentration was noticed. These data were confirmed by the decrease of the OD in the cell debris. These results were in accordance with the data of Kapucu et al. (2000), who investigated ultrasonic disruption of the gram negative bacterium Acetobacter peroxdans. The results in figure 3 show that a further increase of the power towards 90 and $120 \mathrm{~W}$ led to a protein concentration of $13.1 \pm$ 0.6 and $14.8 \pm 0.6$, respectively. Minor changes in OD were observed with an increase in power from 90 to $120 \mathrm{~W}$. A power increase from 60 to $120 \mathrm{~W}$ contributed to an increase of the relative L-AI activity from $61.0 \pm 0.9 \%$ to $92.5 \pm 0.9 \%$. 


\section{MInstitute Macrothink $_{\text {Int }}$}

\subsection{Effect of Sample Volume}

The effect of sample volume on the release of L-AI was studied at a constant power of $120 \mathrm{~W}$, a duty cycle of $50 \%$ and a sonication time of 5 minutes. The sample volume was varied from 30.0 to $120.0 \mathrm{~mL}$. Measurement of the protein concentration and relative L-AI activity in the crude extract and OD of the cell debris was carried out for studying the effect of sample volume on cell disruption (Figure 4).

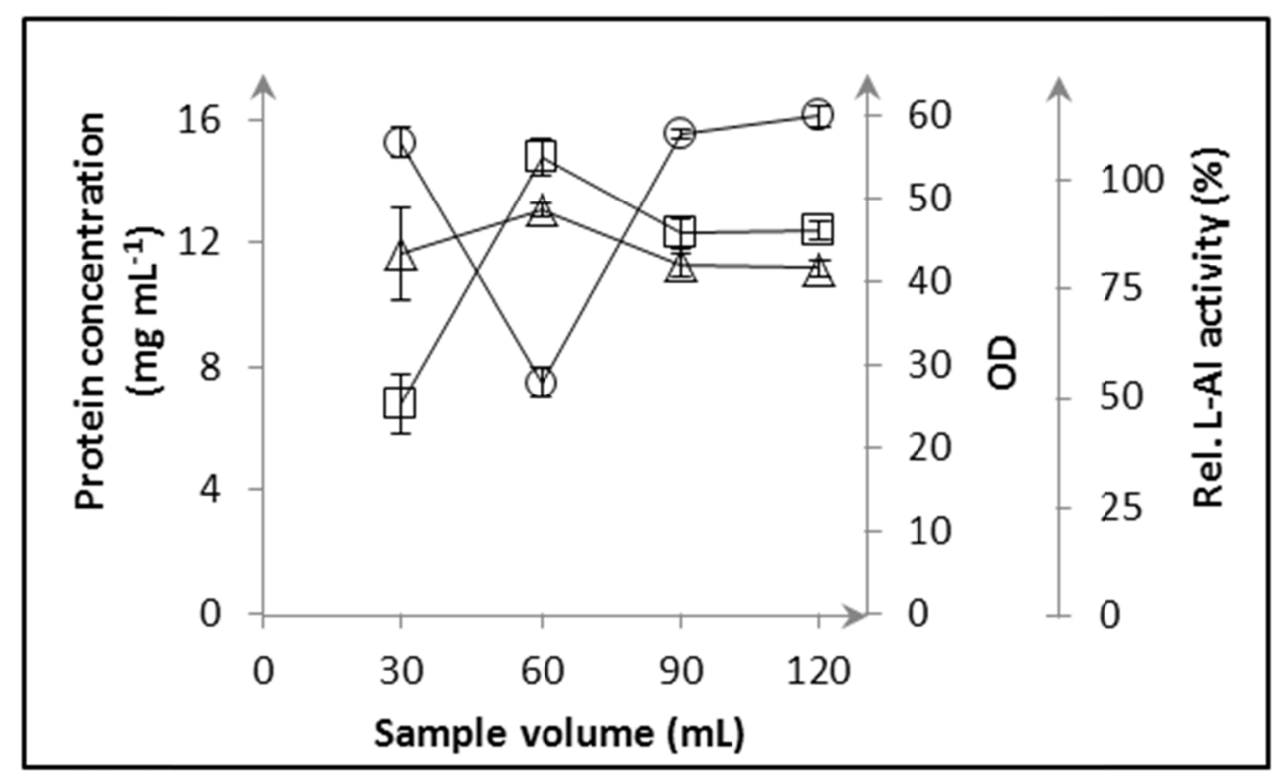

Figure 4. Effect of sample volume on the protein concentration ( $\square$ ) and relative L-AI activity $(\Delta)$ of the crude extract and OD of the cell debris $(\circ)$

A sample volume of $30.0 \mathrm{~mL}$ resulted in a low protein concentration and high OD of the cell debris which can be correlated to a high amount of eddies and shockwaves per volume unit, resulting in inactivation of the L-AI enzyme. The highest protein concentration and relative L-AI activity was found for a sample volume of $60.0 \mathrm{~mL}$, namely $14.8 \pm 0.6 \mathrm{mg} \mathrm{mL}^{-1}$ and $92.5 \pm 0.9 \%$, respectively. Further increase of the volume resulted in a lower protein concentration and relative L-AI activity which can be explained by a decrease of the amount of eddies and shockwaves per volume unit resulting in a lower degree of cell disruption. Thus, a sample volume higher or lower than $60.0 \mathrm{~mL}$ led to a lower relative L-AI activity indicating that a sample volume of $60.0 \mathrm{~mL}$ is preferred for sonication of the cells.

Summarized, the results show that sonication is an effective method for isolation of L-AI from Geobacillus stearothermophilus expressed in E. coli. The experimental data of all investigated parameters show that highest isolation of L-AI enzyme was obtained at $120 \mathrm{~W}$ after 5 minutes sonication, at a duty cycle of $50 \%$ and sample volume of $60.0 \mathrm{~mL}$. 


\subsection{Screening of Chemical Reagents for Cell Disruption}

Cell disruption can also be achieved by a broad range of chemical reagents (Falconer et al., 1997; Geciova et al., 2002; Harrison, 1991; Middelberg, 1995; Naglak \& Wang, 1990; Seddon et al., 2004; Zhao \& Yu, 2001). In this study, different chemical reagents were screened for isolation of the L-AI enzyme from E. coli. More specifically, the detergents triton X-100 and tween80, urea as chaotrope and the solvent isopropanol were studied. The efficiency of these chemical reagents were evaluated by measuring the protein concentration and relative L-AI activity in the crude extract and results are presented in Table 1.

Table 1. Effect of $16.5 \mathrm{mM}$ triton X-100, $8.17 \mathrm{mM}$ tween80, 2.00 M urea and 1.31 M isopropanol at $25^{\circ} \mathrm{C}$ on the protein concentration and relative L-AI activity of the crude extract

\begin{tabular}{lll}
\hline Chemical reagent & Protein conc. $\left(\mathrm{mg} \mathrm{mL}^{-1}\right)$ & Relative L-AI activity $(\%)$ \\
\hline Triton X-100 & $15.1 \pm 1.5$ & $95.6 \pm 1.2$ \\
Tween80 & $11.1 \pm 0.3$ & $50.3 \pm 0.6$ \\
Urea & $7.2 \pm 0.4$ & $33.7 \pm 0.3$ \\
Isopropanol & $3.5 \pm 0.4$ & $27.6 \pm 2.4$ \\
\hline
\end{tabular}

The detergent triton X-100 was most effective for cell disruption of E. coll $i$ cells compared to tween80, urea and isopropanol. These findings are in accordance with the data of Zhao et al. (2001). These authors investigated the release of intracellular proteins from $E$. coli and found an enzyme release of 61.5 and $25.6 \%$ after treatment with triton X-100 and tween80, respectively. During our research, still a higher relative enzyme activity was observed after sonication. A high protein concentration, more specifically $15.1 \pm 1.5 \mathrm{mg} \mathrm{mL}^{-1}$, was found after treatment of washed pellet of the WT enzyme with $16.5 \mathrm{mM}$ triton X-100. Furthermore, a relative L-AI activity of $95.6 \pm 1.2 \%$ was noticed, which is a slightly higher activity compared to the relative L-AI activity which was reached after sonication of the cells $(92.5 \pm$ $0.9 \%$ ). Thus, chemical lysis with triton $\mathrm{X}-100$ resulted in a gain of $3 \%$ in relative L-AI activity compared to sonication. However, the application of chemical reagents will inevitably lead to an increase in costs due to the cost price of the chemical reagents themself, additional purification steps and more complex waste water treatment steps. Treatment of $E$. coli cells with $8.17 \mathrm{mM}$ tween $80,2.00 \mathrm{M}$ urea and $1.31 \mathrm{M}$ isopropanol at $25^{\circ} \mathrm{C}$ resulted in a poor cell disruption compared to triton $\mathrm{X}-100$ and sonication. Furthermore, also the isolation of $\mathrm{WT}_{\mathrm{i}}$ enzyme was examined. $50.0 \mathrm{~mL}$ washed pellet of the $\mathrm{WT}_{\mathrm{i}}$ enzyme was incubated with $16.5 \mathrm{mM}$ triton X-100 during 17 hours at $25^{\circ} \mathrm{C}$. The relative L-AI activity and protein concentration were $13.0 \pm 0.2 \mathrm{~g} \mathrm{~L}^{-1}$ and $84.0 \pm 0.5 \%$, respectively. The L-AI activity and protein concentration were lower compared with chemical treatment of washed pellet of the WT enzyme (see Table 1) although a similar L-AI activity was reached at the end of the fermentation. In order to improve the cell lysis, the effect of treatment time and triton X-100 
concentration were further evaluated.

\subsection{Effect of Treatment Time and Triton X-100 Concentration}

In order to enhance the isolation of the L-AI enzyme ( $\mathrm{WT}_{\mathrm{i}}$ enzyme), the effect of treatment time on chemical cell disruption was thoroughly examined. $50.0 \mathrm{~mL}$ washed pellet of the $\mathrm{WT}_{\mathrm{i}}$ enzyme was incubated with $16.5 \mathrm{mM}$ triton X-100 for 6,17 and 28 hours. Furthermore, the effect of triton X-100 concentration on isolation of L-AI enzyme was evaluated by incubating $50.0 \mathrm{~mL}$ washed pellet of the $\mathrm{WT}_{\mathrm{i}}$ enzyme with $16.5,33.1$ and $49.6 \mathrm{mM}$ triton X-100 during 17 hours at $25^{\circ} \mathrm{C}$ (see Table 2).

Table 2. Effect of treatment time and triton $\mathrm{X}-100$ concentration at $25^{\circ} \mathrm{C}$ on the protein concentration and relative L-AI activity of the crude extract

\begin{tabular}{llll}
\hline & & $\begin{array}{l}\text { Protein conc. } \\
\left(\mathrm{mg} \mathrm{mL}^{-1}\right)\end{array}$ & $\begin{array}{l}\text { Relative L-AI activity } \\
(\%)\end{array}$ \\
\hline \multirow{2}{*}{ Treatment time (h) } & 6 & $13.3 \pm 0.6$ & $79.0 \pm 1.2$ \\
& 17 & $13.0 \pm 0.2$ & $84.0 \pm 0.5$ \\
& 28 & $14.4 \pm 0.8$ & $85.7 \pm 1.3$ \\
& 16.5 & $13.0 \pm 0.2$ & $84.0 \pm 0.5$ \\
Triton X-100 concentration $(\mathrm{mM})$ & 33.1 & $13.3 \pm 0.1$ & $83.7 \pm 1.1$ \\
& 49.6 & $13.3 \pm 0.2$ & $85.9 \pm \mathbf{0 . 9}$ \\
\hline
\end{tabular}

Increasing the treatment time from 6 to 28 hours resulted in an increase in protein concentration from $13.3 \pm 0.6$ to $14.4 \pm 0.8 \mathrm{mg} \mathrm{mL}^{-1}$ and in relative L-AI activity from $79.0 \pm$ 1.2 to $85.7 \pm 1.3 \%$, respectively. Increasing the triton X-100 concentration from 16.5 to 49.6 $\mathrm{mM}$ had no pronounced effect on the protein concentration and only a small increase in relative L-AI activity was noticed, from $84.0 \pm 0.5$ to $85.9 \pm 0.9 \%$, respectively. In the context of the further purification steps in order to implement the enzyme in the biochemical production process of D-tagatose, a detergent concentration of $16.5 \mathrm{mM}$ triton X-100 for 28 hours is preferentially applied. A higher concentration of triton X-100 only resulted in a limited increase in enzyme release, while a higher chemical reagent concentration will negatively influence the cost price of the enzyme. The isolation of $\mathrm{WT}_{\mathrm{i}}$ enzyme was however still less efficient compared to the WT enzyme, viz. a relative L-AI activity of $85.7 \pm 1.3$ and $95.6 \pm 1.2 \%$ was found, respectively. The host organism for both enzymes is E. coli and similar activities were present in the pellet before cell lysis. However, differences are present in the fermentation protocols e.g. fermentation time and temperature. These parameters can have an effect on cell morphology and consequently also on the efficiency of cell disruption. For this reason, a combination of chemical lysis and sonication was examined in order to attempt to increase the isolation of $\mathrm{WT}_{\mathrm{i}}$ enzyme. 


\subsection{Combination of Sonication With Chemical Cell Disruption}

Within these experiments, it was investigated whether isolation of $\mathrm{WT}_{\mathrm{i}}$ enzyme can be enhanced by a combined disruption approach, e.g. sonication and chemical cell disruption with triton X-100. The order of applying different techniques can also play a major role. Sonication was followed by chemical cell lysis and vice versa. Sonication was performed with $60.0 \mathrm{~mL}$ sample volume at $120 \mathrm{~W}$ for 5 minutes with a duty cycle of $50 \%$. Chemical cell lysis was performed in the presence of $16.5 \mathrm{mM}$ triton $\mathrm{X}-100$ at $25^{\circ} \mathrm{C}$ during a short incubation period of 6 hours. In Table 3, the mean value of the protein concentration and relative L-AI activity after cell disruption and the standard deviations are presented. Results of the combined approaches are compared to the results of the individual disruption techniques.

Table 3. Combination of sonication and chemical cell disruption for isolation of L-AI from Geobacillus stearothermophilus

\begin{tabular}{lll}
\hline Disruption method & Protein conc. $\left(\mathrm{mg} \mathrm{mL}^{-1}\right)$ & Relative L-AI activity (\%) \\
\hline Sonication & $12.9 \pm 0.8$ & $79.3 \pm 1.5$ \\
$16.5 \mathrm{mM}$ triton X-100 & $13.3 \pm 0.6$ & $79.0 \pm 1.2$ \\
Sonication + 16.5 mM triton X-100 & $15.1 \pm 0.1$ & $78.8 \pm 1.1$ \\
$16.5 \mathrm{mM}$ triton X-100 + sonication & $16.3 \pm 0.3$ & $89.6 \pm 0.3$ \\
\hline
\end{tabular}

Results in Table 3 show that a combined disruption approach enhanced the protein concentration in the crude extract. An increase in relative L-AI activity is, however, only noticed when chemical lysis was performed prior to sonication resulting in an L-AI activity of $89.6 \pm 0.3 \%$ compared to $79.3 \pm 1.5$ and $79.0 \pm 1.2 \%$ for the individual approaches, e.g., sonication and chemical cell lysis with triton X-100, respectively. The data also illustrated that sonication and chemical lysis with $16.5 \mathrm{mM}$ triton X-100 during 6 hours provided a similar L-AI activity. Sonication of washed pellet of the $\mathrm{WT}_{\mathrm{i}}$ enzyme led to a smaller protein concentration and relative L-AI activity in the crude extract compared to sonication of WT washed pellet (see Figure 1 and Table 3). A protein concentration of $12.9 \pm 0.8$ and $14.8 \pm 0.6$ $\mathrm{mg} \mathrm{mL}^{-1}$ and relative L-AI activity of $79.3 \pm 1.5$ and $92.5 \pm 0.9 \%$ was found for the $\mathrm{WT}_{\mathrm{i}}$ washed pellet and the WT washed pellet, respectively. Through combination of a prior chemical lysis and sonication with washed pellet of the $\mathrm{WT}_{\mathrm{i}}$ enzyme, an increased L-AI activity was reached of $89.6 \pm 0.3 \%$. Thus, isolation of the L-AI enzyme ( $\mathrm{WT}_{\mathrm{i}}$ enzyme) can be improved by a combined disruption approach of a prior chemical lysis with triton X-100 followed by sonication. However, this implies a more complex disruption system, and hence a higher cost price. So, a compromise must be taken into account between the gain in enzyme release and corresponding cost price of the disruption approach.

In this study, different methods were investigated for isolation of Geobacillus stearothermophilus L-AI, intracellularly expressed in E. coli, in the context of the enzymatic 
production of D-tagatose. Several parameters which can influence the efficiency of sonication for isolation of the L-AI enzyme were investigated with washed pellet of the WT enzyme, namely sonication time, duty cycle, power and sample volume. For each parameter, a compromise between maximal cell disruption and minimal enzyme inactivation should be made. The conditions for isolation of L-AI are respectively defined as 5 minutes sonication at $120 \mathrm{~W}$ with a duty cycle of $50 \%$ and sample volume of $60.0 \mathrm{~mL}$. Under these circumstances, a relative L-AI activity in the crude extract was found of $92.5 \pm 0.9 \%$. Next to sonication, different chemicals, e.g., triton X-100, tween80, isopropanol and urea were screened for their efficiency in disrupting the E. coli cell wall. Treatment of washed pellet of the WT enzyme with $16.5 \mathrm{mM}$ of the detergent triton X-100 at $25^{\circ} \mathrm{C}$ for 17 hours gave even better results compared to sonication, namely, a relative L-AI activity in the crude extract of $95.6 \pm 1.2 \%$. Washed pellet of the $\mathrm{WT}_{\mathrm{i}}$ enzyme was also treated with $16.5 \mathrm{mM}$ triton $\mathrm{X}-100$ at $25^{\circ} \mathrm{C}$ for 17 hours. However, a lower L-AI activity was obtained compared to chemical cell lysis of washed pellet of WT enzyme, namely $84.0 \pm 0.5$. Hence, combined disruption approaches for isolation of L-AI enzyme were investigated. A prior chemical lysis followed by a sonication step, led to an increased relative L-AI activity compared to the individual approaches, e.g. chemical lysis and sonication. The relative L-AI activities were $89.6 \pm 0.3 \%, 79.0 \pm 1.2 \%$ and $79.3 \pm 1.5 \%$, respectively. The results indicate that sonication and chemical cell disruption with triton X-100 are effective methods for isolation of the L-AI enzyme from E. coli for further implementation in the D-tagatose production process. Furthermore, the release of recombinant proteins can further be enhanced by a combined disruption approach.

\section{Acknowledgement}

Author Monika Van Holsbeeck is supported by a $\mathrm{PhD}$ grant from KU Leuven (Belgium). Author Jan Van Impe holds the chair Safety Engineering sponsored by the Belgian Chemistry and Life Sciences Federation essenscia. The research was supported by project PFV/10/002 (Center-of-Excellence OPTEC - Optimization in Engineering) of the KU Leuven Research Council, Projects FWO-1518913N \& FWO-G.0930.13 of the Research Foundation Flanders, and Interuniversity Attraction Pole IAP VII/19 (DYSCO - Dynamical Systems, Control and Optimization) of the Belgian Science Policy Office. Additional funding was realized through BAC resources from KU Leuven, Technology Campus Ghent. The authors would also like to thank CIP from the University of Liège (Belgium) for kindly supplying the strain, and the Research Unit Food and Lipids from KU Leuven (Belgium) for the use of the Branson Sonifier 250. Finally, the authors would like to thank Eline Dewachtere for her practical assistance during the sonication experiments.

\section{References}

Agrawal, P. B., \& Pandit, A. B. (2003). Isolation of a-glucosidase from Saccharomyces cerevisiae: cell disruption and adsorption. Biochemical Engineering Journal, 15, 37-45. http://dx.doi.org/10.1016/S1369-703X(02)00178-X

Alzamora, S. M., Guerrero, S. N., Schenk, M., Raffellini, S., \& López-Malo, A. (2011). Inactivation of microorganisms. In H. Feng, G. V. Barbosa-Gánovas, \& J. Weiss (Eds.), Ultrasound technologies for food and bioprocessing (pp. 321-343). New York: Springer. 
http://dx.doi.org/10.1007/978-1-4419-7472-3_12

Ananta, E., Voigt, D., Zenker, M., Heinz, V., \& Knorr, D. (2005). Cellular injuries upon exposure of Escherichia coli and Lactobacillus rhamnosus to high-intensity ultrasound. $\begin{array}{llll}\text { Journal of } \quad \text { Applied } & \text { 271-278. }\end{array}$ http://dx.doi.org/10.1111/j.1365-2672.2005.02619.x

Baneyx, F., \& Mujacic, M. (2004). Recombinant protein folding and misfolding in Escherichia coli. Nature Biotechnology, 22, 1399-1406. http://dx.doi.org/10.1038/nbt1029

Benov, L., \& Al-Ibraheem, J. (2002). Disrupting Escherichia coli: a comparison of methods. Journal of Biochemistry and Molecular Biology, 35, 428-431. http://dx.doi.org/10.5483/BMBRep.2002.35.4.428

Bermúdez-Aguirre, D., Mobbs, T., \& Barbosa-Cánovas, G. V. (2011). Ultrasound applications in food processing. In: H. Feng, G.V. Barbosa-Gánovas, \& J. Weiss (Eds.), Ultrasound technologies for food and bioprocessing (pp. 369-403). New York: Springer. http://dx.doi.org/10.1007/978-1-4419-7472-3_3

Cheetham, P. S. J., \& Wootton, A. N. (1993). Bioconversion of D-galactose into D-tagatose. Enzyme and Microbiology Technology, 15, 105-108. http://dx.doi.org/10.1016/0141-0229(93)90032-W

Dische, Z., \& Borenfreund, E. (1951). A new spectrophotometric method for the detection and determination of keto sugars and trioses. Journal of Biological Chemistry, 192, 583-587.

Falconer, R. J., O’Neill, B. K., \& Middelberg, A. P. J. (1997). Chemical treatment of Escherichia coli: 1. Extraction of intracellular protein from uninduced cells. Biotechnology and Bioengineering, 53, 454-458. http://dx.doi.org/10.1002/(SICI)1097-0290(19970305)53:5<453::AID-BIT2>3.0.CO;2-G

Feliu, J. X., Cubarsi, R., \& Villaverde, A. (1998). Optimized release of recombinant proteins by ultrasonication of E. coli cells. Biotechnology and Bioengineering, 58, 536-540. http://dx.doi.org/10.1002/(SICI)1097-0290(19980605)58:5<536::AID-BIT10>3.0.CO;2-9

Geciova, J., Bury, D., \& Jelen, P. (2002). Methods for disruption of microbial cells for potential use in the dairy industry - a review. International Dairy Journal, 12, 541-553. http://dx.doi.org/10.1016/S0958-6946(02)00038-9

Harrison, S. T. L. (1991). Bacterial cell disruption: a key unit operation in the recovery of intracellular products. Biotechnology Advances, 9, 217-240. http://dx.doi.org/10.1016/0734-9750(91)90005-G

Ho, C. W., Chew, T. K., Ling, T. C., Kamaruddin, S., Tan, W. S., \& Tey, B. T. (2006). Efficient mechanical cell disruption of Escherichia coli by an ultrasonicator and recovery of intracellular hepatitis B core antigen. Process Biochemistry, 41, 1829-1834. http://dx.doi.org/10.1016/j.procbio.2006.03.043

Jorgensen, F., Hansen, O.C., \& Stougaard, P. (2004). Enzymatic conversion of D-galactose to D-tagatose: heterologous expression and characterisation of a thermostable L-arabinose isomerase from Thermoanaerobacter mathranii. Applied Microbiology Biotechnology, 64, 816-822. http://dx.doi.org/10.1007/s00253-004-1578-6

Joyce, E., Phull, S. S., Lorimer, J. P., \& Mason, T. J. (2003). The development and evaluation 
of ultrasound for the treatment of bacterial suspensions. A study of frequence, power and sonication time on cultured Bacillus species. Ultrasonics Sonochemistry, 10, 315-318. http://dx.doi.org/10.1016/S1350-4177(03)00101-9

Kapucu, H., Gülsoy, N., \& Mehmetoglu, U. (2000). Disruption and protein release kinetics by ultrasonication of Acetobacter peroxydans cells. Biochemical Engineering Journal, 5, 57-62. http://dx.doi.org/10.1016/S1369-703X(99)00065-0

Kim, P., Yoon, S.-H., Roh, H.-J., \& Choi, J.-H. (2001). High production of D-tagatose, a potential sugar substitute, using immobilized L-arabinose isomerase. Biotechnology Progress, 17, 208-210. http://dx.doi.org/10.1021/bp000147u

Kim, H.-J., Ryu, S.-A., Kim, P., \& Oh, D.-K. (2003). A feasible enzymatic process for D-tagatose production by an immobilized thermostable L-arabinose isomerase in a packed-bed bioreactor. Biotechnology Progress, 19, 400-404. http://dx.doi.org/10.1021/bp025675f

Kim, P. (2004). Current studies on biological tagatose production using L-arabinose isomerase: a review and future perspective. Applied Microbiology Biotechnology, 65, 243-249. http://dx.doi.org/10.1007/s00253-004-1665-8

Kim, H.-J., \& Oh, D.-K. (2005). Purification and characterization of an L-arabinose isomerase from an isolated strain of Geobacillus thermodenitrificans producing D-tagatose. Journal of Biotechnology, 120, 162-173. http://dx.doi.org/10.1016/j.jbiotec.2005.06.004

Kuboi, R., Umakoshi, H., Takagi, N., \& Komasawa, I. (1995). Optimal disruption methods for the selective recovery of $\beta$-galactosidase from Escherichia coli. Journal of Fermentation and Bioengineering, 79, 335-341. http://dx.doi.org/10.1016/0922-338X(95i)93991-R

Lee, D.-W., Jang, H.-J., Choe, E.-A., Kim, B.-C., Lee, S.-J., Kim, S.-B., et al. (2004). Characterization of a thermostable L-arabinose (D-galactose) isomerase from the hyperthermophilic Eubacterium Thermotoga maritima. Applied and Environmental Microbiology, 70, 1397-1404. http://dx.doi.org/10.1016/0922-338X(95)93991-R

Lee, D.-W., Choe, E.-A., Kim, S.-B., Eom, S.-H., Hong, Y.-H., Lee, S.-J., et al. (2005). Distinct metal dependence for catalytic and structural functions in the L-arabinose isomerases from the mesophilic Bacillus halodurans and the thermophilic Geobacillus stearothermophilus. Archives of Biochemistry and Biophysics, 434, 333-343. http://dx.doi.org/10.1016/j.abb.2004.11.004

Liang, M., Chen, M., Liu, X., Zhai, Y., Liu, X.-W., Zhang, H., et al. (2012). Bioconversion of D-galactose to D-tagatose: continuous packed bed reaction with an immobilized thermostable L-arabinose isomerase and efficient purification by selective microbial degradation. Applied $\begin{array}{llll}\text { Microbiology and Biotechnology, } & \text { 93, }\end{array}$ http://dx.doi.org/10.1007/s00253-011-3638-z

Lu, Y., Levin, G. V., \& Donner, T.W. (2008). Tagatose, a new antidiabetic and obesity control drug. Diabetes, Obesity and Metabolism, 10, 109-134.

Mawson, R., Gamage, M., Terefe, N. S., \& Knoerzer, K. (2011). Ultrasound in enzyme activation and inactivation. In: H. Feng, G. V. Barbosa-Gánovas, \& J. Weiss (Eds.), Ultrasound technologies for food and bioprocessing (pp. 369-403). New York: Springer. http://dx.doi.org/10.1007/978-1-4419-7472-3_14 


\section{MInstitute Macrothink $_{\text {Int }}$}

Middelberg, A. P. J. (1995). Process-scale disruption of microorganisms. Biotechnology Advances, 13, 491-551. http://dx.doi.org/10.1016/0734-9750(95)02007-P

Naglak, T. J., \& Wang, H. Y. (1990). Recovery of a foreign protein from the periplasm of Escherichia coli by chemical permeabilization. Enzyme and Microbial Technology, 12, 603-611. http://dx.doi.org/10.1016/0141-0229(90)90134-C

Oh, D.-K. (2007). Tagatose: properties, applications and biotechnological processes. Applied Microbiology and Biotechnology, 76, 1-8. http://dx.doi.org/10.1007/s00253-007-0981-1

Özbek, B., \& Ülgen, K. Ö. (2000). The stability of enzymes after sonication. Process Biochemistry, 35, 1037-1043. http://dx.doi.org/10.1016/S0032-9592(00)00141-2

Rhimi, M., \& Bejar, S. (2006). Cloning, purification and biochemical characterization of metallic-ions independent and thermoactive L-arabinose isomerase from the Bacillus stearothermophilus US100 strain. Biochimica et Biophysica Acta, 1760, 191-199. http://dx.doi.org/10.1016/j.bbagen.2005.11.007

Sabate, R., de Groot, N. S., \& Ventura, S. (2010). Protein folding and aggregation in bacteria. Cellular and Molecular Life Science, 67, 2695-2715. http://dx.doi.org/10.1007/s00018-010-0344-4

Santos, H. M., Lodeiro, C., \& Capelo-Martinez, J. L. (2009). The power of ultrasound. In: J.-L. Capelo-Martinez (Eds.), Ultrasound in chemistry: analytical applications (pp. 1-16). Weinheim: Wiley-VCH

Seddon, A. M., Curnow, P., \& Booth, P. J. (2004). Membrane proteins, lipids and detergents: not just a soap opera. Biochimica et Biophysica Acta, 1666, 105-117. http://dx.doi.org/10.1016/j.bbamem.2004.04.011

Skytte, U. (2006). Tagatose. In H. Mitchell (Eds.), Sweeteners and Sugar Alternatives in Food Technology (pp. 262-294). Oxford: Blackwell Publishing Ltd. http://dx.doi.org/10.1002/9780470996003.ch14

Vastenavond, C. M., Bertelsen, H., Hansen, S. J., Laursen, R. S., Saunders, J., \& Eriknauer, K. (2012). Tagatose (D-tagatose). In: L.O. Nabors (Eds.), Alternative sweeteners (pp. 197-221). New York: CRC Press.

Zhao, F., \& Yu, J. (2001). L-asparaginase release from Escherichia coli cells with $\mathrm{K}_{2} \mathrm{HPO}_{4}$ and Triton X-100. Biotechnology Progress, 17, 490-494. http://dx.doi.org/10.1021/bp0100124

\section{Copyright Disclaimer}

Copyright reserved by the author(s).

This article is an open-access article distributed under the terms and conditions of the Creative Commons Attribution license (http://creativecommons.org/licenses/by/3.0/). 